\title{
QUEER CRITICISM AS A POST-MODERNIST APPROACH
}

\section{Prof. Hamdi Hameed Yousif (PhD)}

Tikrit University/ College of Education for Women Department of English

\begin{abstract}
:
One of the post-modernist approaches to literary criticism is the queer criticism which has not been evaluated properly. Queer criticism can refer to any piece of literary criticism that interprets a text from a non-straight perspective. Therefore, it includes both lesbian and gay criticism.
\end{abstract}

The aim of this paper, therefore, is to trace the social and political reasons behind the emergence of Queer criticism in the late twentieth century till it acquired momentum in the twenty-first century. After trying to define the terms related to the Queer criticism, the paper tries to examine the poetics of queer (gay and lesbian) literary works and to point out the main characteristic features of this critical approach by identifying the criteria and the textual evidence by which a literary work is labeled queer. It, also tries to shed light on the common features between queer criticism and feminism, on the one hand, and queer criticism and the deconstructuralist approach on the other hand. The final section of the study is a critique which points out the negative aspects of this approach.

\section{I.i. What is Queer?}

Linguistically speaking, the word "queer" was a shameful word until the late twentieth century. The Oxford Advanced Learner's Dictionary (OALD) defines 'queer' as "an offensive word for a homosexual, especially a man, which is, however, also used by some homosexuals about themselves. (OALD: "queer"). Merriam-Webster Dictionary $(M W D)$ says that an important change has occurred on the meaning of 
"queer" over the last two decades, "the newer use is sometimes taken to be offensive, especially by older gay men who fostered the acceptance of gay in these uses and still have a strong preference for it" ("queer"). In Encarta Dictionary it is "an offensive term meaning gay". Annamarie Rustom Jagose, one of the queer theorists, maintains that

the term 'queer' was, at best, slang for homosexual, at worst, a term of homophobic abuse. In recent years 'queer' has come to be used differently, sometimes as an umbrella term for a coalition of culturally marginal sexual self-identifications and at other times to describe a nascent theoretical model which has developed out of more traditional lesbian and gay studies. (Jagose: 1)

According to Tamsin Spargo, "the central defining characteristic was 'object choice', preference for sexual relationship with someone of the same gender as oneself", (Spargo: 33). This evidently means that the term "queer" includes both gays and lesbians.

\section{I.ii. Queer Theory}

The modern age is often described as the age of isms due to the numerous philosophical theories, artistic and literary movements, and critical approaches and theories. Most critics relate the appearance of this literary term "queer" to the late 1980s and early 1990s. Julie Rivkin and Michael Rayan (1998) believe that Queer Theory emerged around the 1980s as a response to the fast-spreading disease, the AIDS which started killing thousands of the gay people. It emerged "both as a way of providing gays and lesbians with a common term around which to unite and a more radical way of calling attention to the issues raised by them" (Rivkin and Ryan: 677$678)$.

Charles E. Bressler asserts that queer theory is "the most recent school of literary criticism to appear in academia" (Bressler: 255). This school, adds Bressler, is influenced by deconstruction, feminism, gay and lesbian studies, psychoanalysis, postcolonialism and other postist theories and it tries to find answers for the following questions: 
What is a man?/ what is a woman?/ What is gender?/ What does it mean to be a heterosexual? Homosexual? Gay? Lesbian? Bisexual? Queer? / What does it mean to be masculine? Feminine? / What does it mean to be human?/What is normal? Abnormal?/What is a "macho" man?/What is love?/What is "forbidden" passion? Forbidden by whom? /What is "unfulfilled" love? What are its causes?/....Who or what in society sanctions or does not sanction the various kinds of love? Heterosexuality? Homosexuality? Bisexuality?....What does it mean to be homophobic? (Bressler: 25556).

Merriam Webster Dictionary (MWD) defines queer theory as "an approach to literary and cultural studies that rejects traditional categories of gender and sexuality" and it assigns 1988 as the date of the first use of this term (MWD: "queer theory"), while Bressler asserts that the exact date of the first use of the term is 1991: "The term was first coined by the gender theorist Teresa de Lauretis in a special edition of the feminist journal Differences entitled Queer Theory: Lesbian and Gay Sexualities, published in 1991" (Bressler: 256).

Bressler traces the origins of queer criticism back to the eighteenth-century feminist, Mary Wollstonecraft, and her book A Vindication to the Rights of Women (1789) and the germination of the feminist theory when women tried to "define for themselves what it means to be a woman", then to Virginia Woolf's A Room of One's Own (1929) where she advocates that women must reject the social norms that construct femaleness and try to "define their own identity", and to a decade later; to Simone de Beauvoir's The Second Sex (1949) where she declares that women should reject being "an object defined and interpreted by men". Feminists attack the essentialists long-held belief that as humans we have an unchangeable nature and that "our sexuality and our gender are determined by our essential features, our true selves that give us our core sense of what we are, our identity and our selfhood" and hence, they agree with social constructivists and with Jacques Derrida's deconstruction (Bressler: 256-57). One's identity, therefore, is not prescribed or determined; it is subjective.

Nevertheless, Michel Faucault (1926-84) the poststructuralist thinker is one of the most influential writers on queer literature. Faucault himself 
was a gay man who died of AIDS in 1984....Faucault's work and life, achievements and demonisations have made him a powerful model for many gay, lesbian and other intellectuals and his analysis of the interrelationships of knowledge, power and sexuality was the most important intellectual catalyst of queer theory. (Spargo: 8)

Queer theory shares some ideas with poststructuralism such as "Jacques Lacan's psychoanalytic models of decentered identity, unstable identity" (Spargo: 40). It also makes use of "Jacques Derrida's deconstruction" (ibid.: 41) of binary oppositions such as man/woman, male/female, masculine/feminine, gay/lesbian, and heterosexual/homosexual. It also makes use of Faucault's "model of discourse, knowledge and power" (ibid.).

In the early 1990s, according to Yaghoubi, many articles and journals were published and conferences held whose main concern was "queer" --both lesbian and gay-- culture. This was to suggest a form of criticism that used "a pejorative signifier of transgressive desire and sexual instability as a metaphor" for the lesbians and homosexuals. Queer readings make use of a variety of postmodern theories such as deconstruction, feminism and psychoanalysis that resulted in confounding identity and particularly sexual identity by underestimating and minimizing sexual difference (Yaghoubi: 105-106).

Homosexuality has existed throughout history, in all types of society, among all social classes and peoples, and it has survived qualified approval, indifference and the most vicious persecution. But what have varied enormously are the ways in which various societies have regarded homosexuality, the meaning they have attached to it, and how those who were engaged in homosexual activity viewed themselves, (Jagose: 15-16). The story of Prophet Lot in the book of Genesis in the Bible who lived with his family in the city of Sodom. "The men of the city were so wicked that God decided to destroy it", and as Picket argues, the Bible is unclear about exactly how they were sinful. In the story God sends two angels to save Lot, a just man, and his family. The men of the city surround the house and demand that Lot bring out his guests so that they may "know" them, with the connotation of "know" certainly being 
sexual. Lot refuses, stating that they are guests. God subsequently destroys Sodom as well as another city, Gomorrah. The story is concerned with homosexuality (Picket: $175)$ and hence the word "sodomite" is derived to refer to homosexuals.

The Holy Quran is more accurate in telling the story of the Lot's community (qawm Lot) in many suras, such as "Hud" sura, verse (aya) 77ff:

When our messengers came to Lut, he was grieved on their account and felt himself powerless (to protect) them, he said: "This is a distress day. And his people came rushing towards him, and they had been long in the habit of practicing abominations. He said: "O my people! Here are my daughters: they are purer for you (if ye marry)! Now fear Allah, and cover me not with disgrace about my guests! Is there not among you a single right-minded man? They said: "Dost thou know we have no need of thy daughters: indeed thou knowest well what we want! (Hud: 7779)

Like Christianity and Judaism, Islam strongly prohibits homosexuality (of both kinds: gay and lesbian) and this is based on the prohibition of any sexual relationship outside the marriage contract and it has its own terms for homosexuals: louti for the sodomite, mukhannath (which literally means effeminate) for the catamite and suhaqiyyat for a lesbian woman (Siker: 128-129)

With these facts in mind, the antiquity of homosexuality (as a practice not as a term), the great number of homosexuals all over the world and the emergence of same-sex marriage in the twenty-first century, no wonder that queer literature and queer criticism start to attract a lot of attention nowadays. In his book Contemporary Gay American Poets and Playwrights: An A-to-Z Guide, Nelson includes sixty-two outstanding gay American authors whose writings, to a certain extent, belong to queer literature.

One can safely say that the main reason behind the emergence of queer literature and queer criticism is the widespread phenomenon of homosexuality and what is lately termed "same-sex" marriage in western societies that it reached devastating numbers. Furthermore, same-sex marriage is acquiring momentum every day with many countries legalizing and legitimatizing it: 
Same-sex marriage (also known as gay marriage) is marriage between two persons of the same biological sex or gender identity. Supporters of legal recognition for same-sex marriage typically refer to such recognition as marriage equality.

Since 2001, ten countries have begun allowing same-sex couples to marry nationwide: Argentina, Belgium, Canada, Iceland, the Netherlands, Norway, Portugal, Spain, South Africa, and Sweden. Same-sex marriages are also performed and recognized in the Brazilian state of Alagoas, Mexico City and parts of the United States. Some jurisdictions that do not perform same-sex marriages recognize same-sex marriages performed elsewhere: Israel, the Caribbean countries of the Kingdom of the Netherlands, parts of the United States, and all states of Brazil and Mexico. Australia recognizes same-sex marriages only by one partner changing their sex after marriage. As of 2012, proposals exist to introduce same-sex marriage in at least ten other countries. (Wikipedia: art: "Same-sex marriage)

Those who support same-sex marriage depend on the pretext of civil rights and according to them, denying gays and lesbians legal access to such a kind of marriage represents discrimination based on sexual orientation

According to Nelson, Certain foundational texts, such as dictionaries, sourcebooks, and encyclopedias, are indispensable for the legitimization as well as institutionalization of any distinct and emergent field of knowledge. Those books collect, organize, and present primary data about the subject (Nelson: 12). On the other hand, the rapid development and consolidation of lesbian and gay studies in universities in the 1990s and the publication of numerous journals and magazines supporting and promoting the civil rights of queer people, such as The Advocate Los (Angeles, CA); Alternative Family Magazine; Curve Magazine (San Francisco, CA) ; Gay Parents Magazine (Forest Hills, NY) ; Girlfriends; Lesbian News; Our World (gay travel); Out Magazine (Los Angeles, CA); Whosoever (gay Christian magazine), (Sember:11ff).

Apart from the human and civil rights of queer people, "queer" is one of the absolutely negative aspects and products of modern culture. It has disparaging effects on human society starting with the smallest and essential social unit; the family. On the other hand, queer literature which is written in the late nineteenth and early 
twenty-first century mainly deals with the persecution inflicted on queer, gay and lesbian people, by society ignoring the devastating harm they do in return. The current queer criticism, nonetheless, is also partial and rather subjective especially when the critic himself/herself is gay or lesbian. Most of the critics do not approach the work from a psychological point of view and the protagonist as suffering from a psychological disorder.

\section{A Queer Reading of "Brokeblack Mountain"}

One of the earliest works of fiction in which the term "queer" is used and which frankly deals with queer sexuality is Annie Proulx's short story "Brokeback Mountain" which was originally published in The New Yorker on October 13, 1997 and two years later, in 1999, it was published in a slightly expanded version in Close Range: Wyoming Stories. The story was also published separately in book form in the same year.

The story won O. Henry Award Prize (third place) in 1998, the National Magazine Award for fiction, 1998 and Pulitzer Prize in fiction 2000 and in 2005 it was adapted for the film of the same name, by screenwriters Larry McMutry and Diana Ossana (Wikipedia). Bressler describes the movie based on this story as "the most discussed and controversial Hollywood movie in 2005" (Bressler: 252) and the reason was, no doubt, the audacious theme of the story.

In "Brokeback Mountain", the omniscient narrator, in a realistic tone describes events that extend over twenty years in American actual settings. The plot of this short story is overtly homosexual. Specifically, one can argue that the writer presents homosexuality as if it is a healthy romantic love. The two 19-year-old protagonists Ennis Del Mar and Jack Twist who are hired in 1963 by the sheep farmer Joe Aguirre to herd his sheep in Wyoming. After a few days of work, they "found a bar and drunk beer through the afternoon..." (Proulx: 7) and after heavy drinking they slept together and their "queer" relationship started: 
Jack seized his [Ennis] left hand and brought it to his erect cock. Ennis jerked his hand away as though he'd touched fire, got to his knees, unbuckled his belt, shoved his pants down, hauled Jack unto all him, nothing he'd done before but no instruction manual needed. They went at it in silence except for a few sharp intakes of breath Ennis and Jack's choked "gun's goin off," then out, down, and asleep. (Proulx: 11)

However, the two enjoyed their intimate relationship after that night, "in the full daylight with the hot sun striking down, and at evening in the fire glow, quick, rough, laughing and snorting, no lack of noises, but saying not a goddamn word except once Ennis said, "I'm not queer," and Jack jumped in with "Me neither. A one-shot thing. Nobody's business but ours" (Proulx: 11).

At the end of summer the two parted hoping to work together the next summer Ennis marries his longtime fiancée Alma Beers but when Jack came the following summer, his boss told him that he didn't want homosexual workers, he moved to Texas meets and marries Laureen Newsome and has a son from her. Two years later, Jack visits Ennis and the two kiss passionately as lovers and this is inadvertently seen by Alma. Jack proposes living together on a small ranch but Ennis is unenthusiastic to leave his family.

Tell you what, we could a had a good life together, a fuckin real good life. You would do it, Ennis, so what we got now is Brokeback Mountain. Everything built on that. It's all we got, boy, fuckin all, so I hope you know that if you don't never know the rest. Count the damn few times we been together in twenty years. Measure the fuckin short leash you keep me on, then ask me about Mexico and then tell me you'll kill me for needin it and not hardly never getting it. You got no fuckin idea how bad it gets. I'm not you. I can't make I on a couple a highaltitude fuck once or twice a year. You are too much for me, Ennis, you son of a whoreson bitch. I wish I knew how to quit you. (Proulx: 26)

However, they continue to meet in occasional fishing trips. Ennis sees his family regularly until Alma finally confronts him about her knowledge of the true nature of his relationship with Jack which incites a violent argument and causes Ennis to abandon his connections and they divorce in 1975. Jack's marriage is also in trouble; Laureen becomes a businesswoman with her father and hearing about Ennis's divorce, Jack goes to Wyoming in hope of leading a romantic life with Ennis but 
Ennis refuses to abandon his daughters. Jack goes to find an alternative with a male prostitute in Mexico, Ennis has a short-lived romantic relationship with a waitress. Jack begins to have a homosexual affair with Randall, the husband of his wife's friend Lashawn Malone.

The story ends with the Jack's death by an accident, "Jack was pumping up a flat [tire] on the truck out on a back road when the tire blew up. The bead was damaged somehow and the force of the explosion slammed the rim into his face, broke his nose and jaw and knocked him unconscious on his back.... He had drowned in his blood" (Proulx:28). Ennis knows about Jack's death when he sends him a postcard but it is returned stamped "Deceased". In a brief telephone conversation, Lureen tells Ennis that Jack died when a tire he was changing exploded. Lureen tells Ennis that Jack wanted to have his ashes scattered on Brokeback Mountain, but she does not know where it is. Ennis travels to meet with Jack's mother and father, where he offers to take Jack's ashes. The story ends with Ennis left alone struggling with his passionate love for Jack.

How does Annie Proulx represent the social and psychological conflicts of homosexuality? How does her representation of the homosexual relationship between Ennis and Jack exceed traditional definitions of gender and sexuality? What does the writer want her readers to understand about the gay relationship between the protagonists? These and some other questions may be asked to futher explore the queer nature of this work.

Ennis's father had told him to hate homosexuals and that they are hated by society. He told him the story of two homosexuals who were killed by the townspeople and that is why he is always haunted by this childhood memory. Even at the end of the story when he hears of Jack's death in an accident, he believes that he was killed, may be, because of his homosexuality. 
Proulx's narrative tone, from the very beginning of the story represents Ennis and Jack as gay lovers as if there is no polar opposition between homosexuality and heterosexuality. When they get married, they become heterosexual for some time and this goes with what Lois Tyson says:

Queer theory defines individual sexuality as a fluid, fragmented, dynamic collectivity of possible sexualities. Our sexuality may be different at different times over the course of our lives or even at different times over the course of a week because sexuality is a dynamic range of desire. Gay sexuality, lesbian sexuality, bisexuality, and heterosexuality are, for all of us, possibilities along a continuum of sexual possibilities.(Tyson: 335)

Through this representation, therefore, the writer intends to give a positive image of queer (gay) love and sexuality, telling the readers that they are normal people who can be heterosexual, can fall in love and get married as well. She also contradicts traditional definitions of gender and sexuality. She contradicts the essentialists belief in the unchangeable nature of men and that one's sexuality and gender are determined by one's essential features; agreeing with social constructivists and with Jacques Derrida one's right to determine his/her identity. Thus Jack and Ennis, by choice live as lover and beloved; as husband and wife.

One tends to agree with Mark Asquith idea that "the denial of their homosexuality seems hollow; the narrator's apposite double-negative in Ennis's statement 'I'm not no queer' indicates a confused lack of acceptance, while his visceral retching suggests that he is both love-sick and sickened by his behavior, (Asquith: 88-89). He further adds that their

subsequent marriages are attempts "to conform to safer sexual stereotypes, and the failure of these heterosexual relations as predictable due to their latent homosexuality" (89)

Proulx's presentation of Ennis's denial of being queer, his refusal to leave his family and the fear of persecution represented by his memories of the story told by his father all suggest the societal persecution of homosexuals. The two shirts (his and Jack's), according to Asquith, "become a symbol of their repressed love: 'The shirts 
hanging on a nail shudder slightly', the intransitive 'shudder' implying both sexual excitement and fear - an apt description of their relationship" (Asquith: 94).

The successful reception of "Brokeblack Mountain", both as a story and a movie, and the prizes it won is ample evidence that the American society, in general, approves of homosexuality which is cancer-like destroying the humanitarian values and ties. Such a society is doomed to deteriorate and collapse.

\section{Conclusion}

Queer theory did not spring full-blown from the head of any contemporary theorist. It is the outcome of many different influences and sources, including the homophile movement, gay liberation, and lesbian feminism. Due to universal development in civil rights and legalization of same-sex marriage in many countries, queer literature starts to flourish and to have its practitioners and advocators in poetry, fiction and drama. Annie Proulx's "Brokeblack Mountain" can be described as pro-queer story in the sense that the writer adopts the queer point of view through the romantic presentation of the love relationship between two male friends; one can say that it is an advertisement of homosexuality. She also presents them as persecuted rather than abnormal and she makes the reader sympathize with them instead of presenting them as filthy and repulsive. Queer criticism should take into consideration the social, religious and psychological context, otherwise, it will be one-sided and lacking in objectivity.

It is recommended, therefore, that extensive objective studies of queer literature should be conducted trying to analyze in depth the reasons that drive a man or a woman to be queer and the harmful effects of queer sexuality on both individuals and societies. 


\section{Bibliography}

-Asquith, Mark. Annie Proulx: Brokeback Mountain and Postcards. London: Continuum Books 2009

-Bressler, Charles E. Literary Criticism: An Introduction to Theory and Practice. Upper Saddle River: Pearson Education, 2007.

-Hornby, A. S. Oxford Advanced Learner's Dictionary, 7th edition. Oxford: OUP, 2005.

-Jagose, Annamarie Rustom. Queer Theory: An Introduction. New York: New York University Press, 2005.

-Nelson, S. Emmanuel. Contemporary Gay American Poets and Writers: An A-to-Z Guide. London: Greenwood Press, 2003.

-Pickett, Brent L. The A to Z of Homosexuality, (the A to Z Guide Series, No. 122). Plymouth: The Scarecrow Press, Inc., 2009.

- Proulx, Annie Brokeblack Mountain. Dead Line Ltd., 1999.

-Rivkin, Julie and Michael Ryan (eds.). Literary Theory: An Anthology. Malden: Blackwell Publishers Inc., 2000.

- Sember, Brette McWhorter. Gay and Lesbian Rights: A Guide for GLBT Singles, Couples and Families. Naperville: Sphinx Publishing, 2003

-Siker, Jeffrey S. (ed.). Homosexuality and Religion: An Encyclopedia. London: Greenwood Press, 2007.

-Spargo, Tamsin . Foucault and Queer Theory (Postmodern Encounters Series). New York: Totem Books, 2000.

-Tyson, Lois. Critical Theory Today: A User Friendly Guide. New York: Taylor and Francis Group, 2006.

-Yaghoubi, Roya. Key Terms and Theories connected with Postmodernism. Tehran: Rehnama, 2013.

-www.wikipedia.com. 